\title{
Microbacterium luticocti sp. nov., isolated from sewage sludge compost
}

\author{
Ivone Vaz-Moreira, ${ }^{1}$ Ana R. Lopes, ${ }^{2}$ Enevold Falsen, ${ }^{3}$ Peter Schumann, ${ }^{4}$ \\ Olga C. Nunes ${ }^{2}$ and Célia M. Manaia ${ }^{1}$ \\ ${ }^{1}$ Escola Superior de Biotecnologia, Universidade Católica Portuguesa, 4200-072 Porto, Portugal \\ ${ }^{2}$ LEPAE - Departamento de Engenharia Química, Faculdade de Engenharia, Universidade do Porto, \\ 4200-465 Porto, Portugal \\ ${ }^{3}$ Culture Collection University Göteborg, Department of Clinical Bacteriology, S-41346 Göteborg, \\ Sweden \\ ${ }^{4} \mathrm{DSMZ}$ - Deutsche Sammlung von Mikroorganismen und Zellkulturen GmbH, Inhoffenstraße 7B, \\ D-38124 Braunschweig, Germany
}

Correspondence

Célia M. Manaia cmmanaia@esb.ucp.pt

\begin{abstract}
Strain SC-087B ${ }^{\top}$, isolated from sewage sludge compost during a study of bacterial diversity in composts, was characterized. The isolate was a Gram-positive, short rod that was motile, catalase- and oxidase-negative and able to grow at $27-45^{\circ} \mathrm{C}, \mathrm{pH} 5.5-9.7$ and in up to $10 \%$ $\mathrm{NaCl}$. The peptidoglycan was of the $\mathrm{B} 2 \beta$ type, containing the characteristic amino acids ornithine, homoserine and hydroxyglutamic acid. The muramic acid residues of the peptidoglycan were partially glycolylated. The major cell-wall sugar was mannose; traces of xylose were also detected. The predominant fatty acids, comprising more than $70 \%$ of the total, were anteiso- $\mathrm{C}_{17: 0}$ and anteiso- $C_{15: 0}$, the major respiratory quinone was menaquinone-12 (MK-12) and the $G+C$ content of the genomic DNA was $72 \mathrm{~mol} \%$. Based on analysis of the 16S rRNA gene sequence, the closest phylogenetic neighbours of strain SC-087 $\mathrm{B}^{\top}$ were members of the family Microbacteriaceae, showing sequence similarity values of around $96 \%$ with members of the species Microbacterium barkeri (96.0\%), Microbacterium gubbeenense (95.6\%) and Microbacterium indicum (95.7\%). The chemotaxonomic and phenotypic traits analysed supported the inclusion of this strain within the genus Microbacterium and the proposal of a novel species. The name Microbacterium luticocti sp. nov. is proposed and the type strain is $\mathrm{SC}-087 \mathrm{~B}^{\top}$ $\left(=\right.$ DSM $19459^{\top}=$ CCUG $\left._{54537^{\top}}\right)$.
\end{abstract}

Composting is the biological decomposition of organic matter under aerobic conditions to produce a humus-like product that can be used for gardening or as a soil corrective. During this process, temperatures around $60{ }^{\circ} \mathrm{C}$ are reached, imposing stressful thermal conditions on the mesophilic microbiota (Epstein, 1997). In spite of this, mesophilic bacteria belonging to different phyla have been isolated from thermal composts (Tiago et al., 2004; VazMoreira et al., 2008).

This paper describes a bacterial strain, designated SC$087 \mathrm{~B}^{\mathrm{T}}$, isolated from municipal sewage sludge compost (Vaz-Moreira et al., 2008). This compost was produced in a windrow digester from anaerobically digested sludge of a municipal wastewater treatment plant mixed with granular pine bark. 16S rRNA gene sequence analysis revealed that strain $\mathrm{SC}-087 \mathrm{~B}^{\mathrm{T}}$ was affiliated to the family

The GenBank/EMBL/DDBJ accession number for the 16S rRNA gene sequence of strain SC-087B' is AM747814.
Microbacteriaceae, with members of the genus Microbacterium as the closest neighbours (Takeuchi \& Hatano, 1998a). This genus currently comprises more than 50 recognized species (Euzéby, 1997), including isolates from a broad range of origins, namely soil, air, water, dairy products, plant galls, insects, clinical samples and even culture contaminants (Takeuchi \& Hatano, 1998b; Matsuyama et al., 1999; Behrendt et al., 2001; Schippers et al., 2005; Richert et al., 2007).

The isolate was purified by subculturing on plate count agar (PCA) and maintained on brain heart infusion (BHI) agar. Cultures were incubated at $30{ }^{\circ} \mathrm{C}$ and cells were stored at $-80{ }^{\circ} \mathrm{C}$ in nutritive broth with $15 \%(\mathrm{v} / \mathrm{v})$ glycerol for preservation. Colony and cell morphologies, Gram-staining, cytochrome $c$ oxidase and catalase tests, production of endospores and motility were analysed based on the methodologies of Murray et al. (1994) and Smibert \& Krieg (1994). Unless otherwise stated, all biochemical and physiological tests were performed as described 
previously (Vaz-Moreira et al., 2007). Biochemical and nutritional tests were performed using the API 20E, API 20NE and API 50CH galleries (bioMérieux) according to the manufacturer's instructions. The API $50 \mathrm{CH}$ gallery was assayed with the medium recommended to test acid production (50 CHB/E; bioMérieux) and with AUX medium (bioMérieux) to test assimilation of sole carbon sources. Antibiotic susceptibility was assayed as described previously (Ferreira da Silva et al., 2006).

The genomic DNA G $+\mathrm{C}$ content (mol\%) and respiratory quinones were analysed as described by Vaz-Moreira et al. (2007) using the methods of Mesbah et al. (1989) and Tindall (1989), respectively. Fatty acid methyl esters were analysed on $24 \mathrm{~h}$ cultures on Columbia II agar base (BBL 4397596 ) with $5 \%$ horse blood at $37{ }^{\circ} \mathrm{C}$, according to the prevailing MIDI Sherlock MIS procedures (further outlined at http://www.ccug.se/pages/cfanew.pdf). Purified peptidoglycan preparations were obtained after disruption of cells by shaking with glass beads and subsequent trypsin digestion according to the method of Schleifer \& Seidl (1985). The amino acid composition of the peptidoglycan hydrolysate $\left(4 \mathrm{M} \mathrm{HCl}, 16 \mathrm{~h}, 100{ }^{\circ} \mathrm{C}\right)$ was determined by one-dimensional TLC on cellulose plates (Merck) by using the solvent system of Rhuland et al. (1955) and by GC of amino acids (Schumann et al., 1997) after derivatization according to MacKenzie (1987). The sugar composition of the purified cell wall was analysed by TLC on cellulose plates employing the method of Staneck \& Roberts (1974). Glycolyl residues were detected in the peptidoglycan by using the method described by Uchida et al. (1999).

The nucleic acid sequence of the $16 \mathrm{~S}$ rRNA gene was determined after PCR amplification of total DNA extracts as described previously (Ferreira da Silva et al., 2007). The 16S rRNA gene sequence was compared with others available in the GenBank/EMBL/DDBJ database using the FASTA package from EMBL-EBI. Phylogenetic analyses were conducted using MEGA software version 3.1 (Kumar et al., 2004). Sequence relatedness was estimated based on the model of Jukes \& Cantor (1969) and the phylogenetic tree was created using the neighbour-joining method (Fig. 1). Additionally, the maximum-parsimony method was used to confirm tree stability. A total of $1285 \mathrm{nt}$ positions in each $16 \mathrm{~S}$ rRNA gene sequence was included in the analysis. Non-homologous and ambiguous nucleotide positions were excluded from the calculations.

Strain SC-087B ${ }^{\mathrm{T}}$ formed convex, white, opaque colonies of 1-2 mm diameter after $48 \mathrm{~h}$ incubation at $30{ }^{\circ} \mathrm{C}$ on $\mathrm{BHI}$

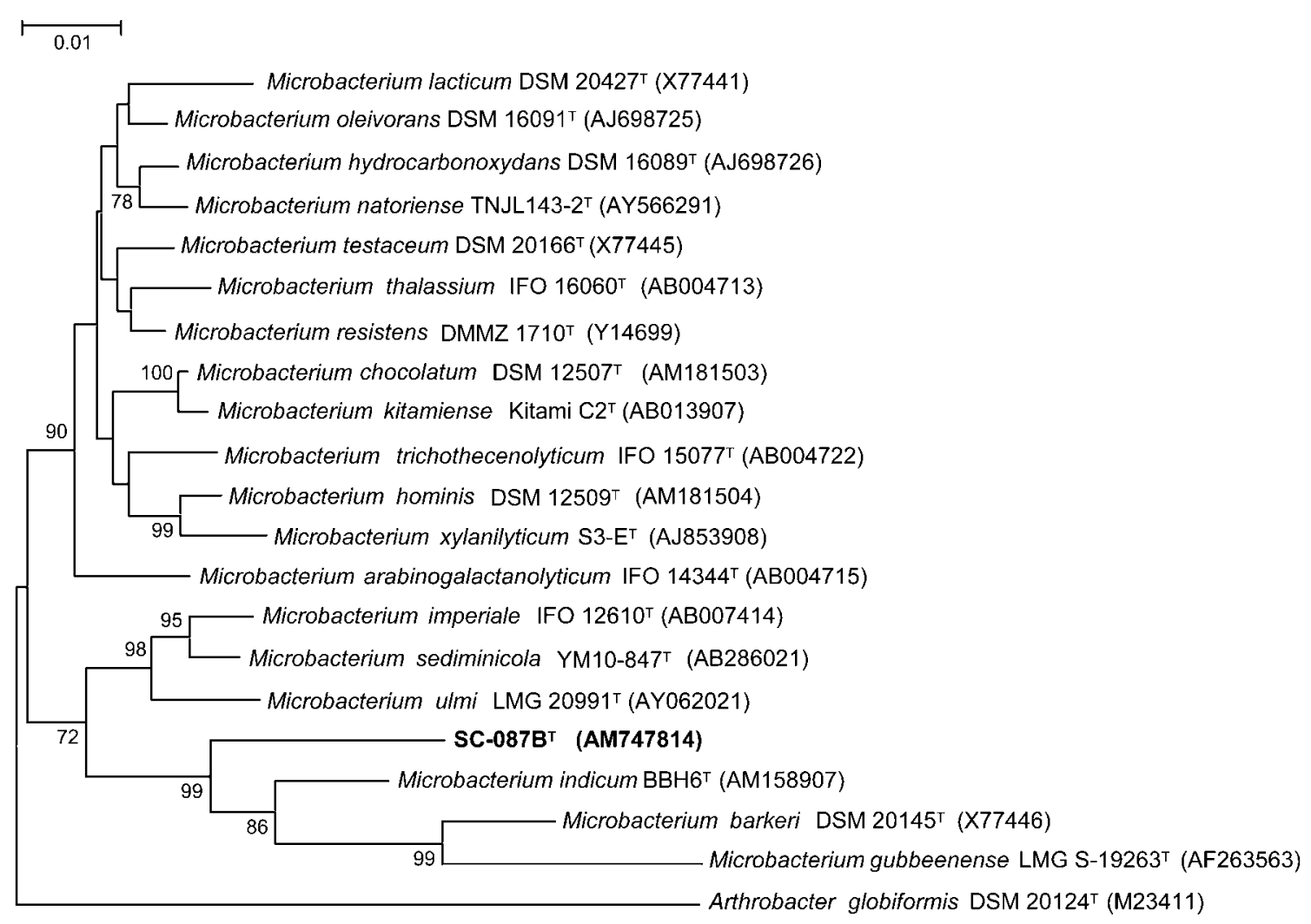

Fig. 1. Phylogenetic tree based on $16 \mathrm{~S}$ rRNA gene sequences showing the nearest neighbours of strain SC-087B $\mathrm{B}^{\top}$. A total of $1285 \mathrm{nt}$ positions in each 16S rRNA gene sequence was included in this analysis. Arthrobacter globiformis DSM $20124^{\top}$ (M23411) was used as outgroup. Bootstrap values were generated from 1000 resamplings; only values greater than $70 \%$ are shown. Bar, 1 substitution per 100 nt positions. 
agar. Slower and poorer growth was observed on other nutritional media, e.g. PCA and Luria-Bertani agar. Cell viability was weakened or lost after periods of culture transfer longer than a week. The results of the phenetic characterization of strain $\mathrm{SC}-087 \mathrm{~B}^{\mathrm{T}}$ are summarized in Table 1. The peptidoglycan contained the amino acids ornithine, homoserine, glycine, alanine and glutamic acid. The molar ratio of glycine to glutamic acid was $1.7: 1.0$ and the glutamic acid was partially hydroxylated. Analytical data suggested the presence of peptidoglycan type $\mathrm{B} 2 \beta$ in strain $\mathrm{SC}-087 \mathrm{~B}^{\mathrm{T}}$. The muramic acid residues of the peptidoglycan were partially glycolylated. Mannose and traces of xylose were detected as cell-wall sugars. The major fatty acid methyl esters of this organism were anteiso- $\mathrm{C}_{17: 0}$ $(43.6 \%)$ and anteiso- $\mathrm{C}_{15: 0}(32.9 \%)$. Other minor components were iso- $\mathrm{C}_{15: 0}(9.5 \%)$, iso- $\mathrm{C}_{16: 0}(9.2 \%)$ and iso$\mathrm{C}_{17: 0}(3.0 \%)$. The DNA G $+\mathrm{C}$ content determined for strain SC-087B ${ }^{\mathrm{T}}$ was $72 \pm 0.3 \mathrm{~mol} \%$. Menaquinone MK-12 was the major respiratory quinone, with MK-11 and MK10 as minor components (76, 23 and $1 \%$, respectively).

The closest neighbours of strain $\mathrm{SC}-087 \mathrm{~B}^{\mathrm{T}}$ based on analysis of the $16 \mathrm{~S}$ rRNA gene sequence were
Microbacterium barkeri ( $96.0 \%$ sequence similarity), Microbacterium gubbeenense $(95.6 \%$ similarity) and Microbacterium indicum ( $95.7 \%$ similarity). Important features described for the genus Microbacterium include: the predominance of iso- and anteiso-branched fatty acids; the presence of alanine, D-glutamic acid and either L-lysine, L-ornithine or L-homoserine in the peptidoglycan with an interpeptide bridge containing lysine or Dornithine; muramic acid in the $\mathrm{N}$-glycolyl form; the occurrence of MK-11 and MK-12 as major menaquinones; and a genomic DNA G+C content of $66-72 \mathrm{~mol} \%$ (Takeuchi \& Hatano, 1998a). Thus, on the basis of its chemotaxonomic characteristics, fatty acid and peptidoglycan composition, respiratory menaquinones and genomic DNA G $+C$ content, strain $\mathrm{SC}-087 \mathrm{~B}^{\mathrm{T}}$ can be considered to be a member of the genus Microbacterium. However, 16S rRNA gene sequence similarity values with members of this genus, as well as the existence of distinctive characteristics (Table 1), justify the proposal of a novel species within the genus Microbacterium for which the name Microbacterium luticocti sp. nov. is proposed.

Table 1. Characteristics of strain SC-087B ${ }^{\top}$ and the type strains of the related species $M$. barkeri, M. gubbeenense and M. indicum

Species/strains: 1, SC-087B ${ }^{\text {T }}$ 2, M. barkeri (data from Komagata \& Suzuki, 1984; Takeuchi \& Hatano, 1998b; Brennan et al., 2001); 3, M. gubbeenense (Brennan et al., 2001; Shivaji et al., 2007); 4, M. indicum (Shivaji et al., 2007). +, Positive; -, negative; W, weak reaction; NA, no available data.

\begin{tabular}{|c|c|c|c|c|}
\hline Characteristic & 1 & 2 & 3 & 4 \\
\hline Catalase & - & + & + & - \\
\hline Motility & + & + & + & NA \\
\hline $\mathrm{H}_{2} \mathrm{~S}$ production & - & + & - & NA \\
\hline \multicolumn{5}{|l|}{ Growth at/in: } \\
\hline $40{ }^{\circ} \mathrm{C}$ & + & + & - & - \\
\hline $8 \% \mathrm{NaCl}$ & + & - & + & - \\
\hline \multicolumn{5}{|l|}{ Hydrolysis of: } \\
\hline Starch & $\mathrm{w}$ & + & - & - \\
\hline Gelatin & + & + & - & NA \\
\hline Urease activity & + & - & - & - \\
\hline \multicolumn{5}{|l|}{ Utilization of: } \\
\hline L-Arabinose & - & + & + & + \\
\hline Citrate & - & + & + & - \\
\hline Malate & - & + & + & NA \\
\hline \multicolumn{5}{|l|}{ Acid from: } \\
\hline Arabinose & - & + & + & + \\
\hline D-Galactose & $\mathrm{w}$ & - & + & - \\
\hline D-Glucose & - & - & + & + \\
\hline L-Rhamnose & + & + & - & - \\
\hline Major fatty acids* & ai-C15, ai-C17 & ai-C15, ai-C17, i-C16 & ai-C15, ai-C17, i-C16 & $\begin{array}{c}\text { ai-C15, ai-C17, i-C16, } \\
\text { C16 }\end{array}$ \\
\hline Cell wall diamino acid & Orn & Orn & Lys & Orn \\
\hline Predominant menaquinones & 12 and 11 & 11 and 12 & 11 and 12 & 11 and 12 \\
\hline DNA G $+\mathrm{C}$ content $(\mathrm{mol} \%) \dagger$ & 72 & $68\left(T_{\mathrm{m}}\right)$ & $72\left(T_{\mathrm{m}}\right)$ & $66\left(T_{\mathrm{m}}\right)$ \\
\hline Source & Sewage sludge compost & Raw domestic sewage & Smear-ripened cheese & Deep-sea sediment \\
\hline
\end{tabular}

*ai, anteiso; i, iso.

$\dagger T_{\mathrm{m}}$, Determined using the thermal denaturation method. 


\section{Description of Microbacterium luticocti sp. nov.}

Microbacterium luticocti (L. neut. n. lutum mud, sludge; L. part. adj. coctus - $a$-um digested; N.L. gen. n. luticocti of digested sludge).

Colonies are white, opaque and circular (1-2 mm diameter) on BHI agar. Cells are Gram-positive, short rods $(1.6 \pm 0.3 \mu \mathrm{m}$ long and $0.5 \pm 0.1 \mu \mathrm{m}$ wide) that are nonspore-forming and motile. Catalase- and oxidase-negative. Growth occurs between 27 and $45{ }^{\circ} \mathrm{C}$, between pH 5.5 and 9.7 and in the presence of up to $10 \% \mathrm{NaCl}$, with optimum growth around $36{ }^{\circ} \mathrm{C}, 1-3 \% \mathrm{NaCl}$ and $\mathrm{pH}$ 8. Growth does not occur at $25{ }^{\circ} \mathrm{C}$ or $47^{\circ} \mathrm{C}$, at $\mathrm{pH} 5$ or pH 10 , or in $12 \%$ $\mathrm{NaCl}$. Nitrate is reduced to nitrite, but does not support anaerobic growth. Starch, gelatin and aesculin are hydrolysed. Urease and $\beta$-galactosidase are produced. Acid is produced from D-arabitol, D-fructose, D-mannitol, L-rhamnose, sucrose and trehalose and produced weakly from cellobiose, L-fucose, D-galactose, maltose, D-mannose, potassium 5-ketogluconate and turanose. The following sole carbon sources are assimilated: $N$-acetylglucosamine, amygdalin, D-arabinose, cellobiose, D-fructose, L-fucose, Dgalactose, gentiobiose, D-lactose, maltose, D-mannitol, Dmannose, potassium gluconate, L-rhamnose, D-ribose, salicin and trehalose. Poor growth is observed when glucose is the single carbon source. Growth occurs in the presence of ciprofloxacin $(5 \mu \mathrm{g})$, meropenem $(10 \mu \mathrm{g})$, ceftazidime $(30 \mu \mathrm{g})$, colistin sulfate $(50 \mu \mathrm{g})$ and sulfamethoxazole $(25 \mu \mathrm{g})$. Unable to assimilate L-arabinose, caprate, adipate, malate, citrate, phenylacetate, glycerol, erythritol, L-arabinose, D-xylose, L-xylose, D-adonitol, methyl $\beta$-D-xylopyranoside, L-sorbose, dulcitol, inositol, D-sorbitol, methyl $\alpha$-Dmannopyranoside, methyl $\alpha$-D-glucopyranoside, arbutin, melibiose, sucrose, inulin, melezitose, raffinose, starch, glycogen, xylitol, turanose, D-lyxose, D-tagatose, D-fucose, D-arabitol, L-arabitol, potassium 2-ketogluconate or potassium 5-ketogluconate. Does not produce acid from glycerol, erythritol, D-arabinose, L-arabinose, D-ribose, Dxylose, L-xylose, D-adonitol, methyl $\beta$-D-xylopyranoside, Dglucose, L-sorbose, dulcitol, inositol, D-sorbitol, methyl $\alpha$-Dmannopyranoside, methyl $\alpha$-D-glucopyranoside, $N$-acetylglucosamine, amygdalin, arbutin, salicin, D-lactose, melibiose, inulin, melezitose, raffinose, starch, glycogen, xylitol, gentiobiose, D-lyxose, D-tagatose, D-fucose, L-arabitol, potassium gluconate or potassium 2-ketogluconate. Cannot ferment or oxidize (API 20E) D-glucose, Dmannitol, inositol, D-sorbitol, sucrose, melibiose, amygdalin or L-arabinose. Negative for Tweenase, $\beta$-galactosidase, arginine dihydrolase, lysine and ornithine decarboxylases, citrate utilization, and indole and acetoin production. Unable to grow in the presence of amoxicillin $(25 \mu \mathrm{g})$, gentamicin $(10 \mu \mathrm{g})$, tetracycline $(30 \mu \mathrm{g})$, SXT (sulfamethoxazole/trimethoprim, 23.5/1.25 $\mu \mathrm{g})$, cephalothin $(30 \mu \mathrm{g})$, streptomycin $(10 \mu \mathrm{g})$ or ticarcillin $(75 \mu \mathrm{g})$. The fatty acids anteiso- $\mathrm{C}_{17: 0}$ and anteiso- $\mathrm{C}_{15: 0}$ comprise more than $70 \%$ of the total. The peptidoglycan is of the B2 $\beta$ type and contains glycolyl residues. Mannose is the cell-wall sugar. MK-12 is the major respiratory quinone.
The type strain is $\mathrm{SC}-087 \mathrm{~B}^{\mathrm{T}}\left(=\mathrm{DSM} 19459^{\mathrm{T}}=\mathrm{CCUG}\right.$ $\left.54537^{\mathrm{T}}\right)$, isolated from sewage sludge compost. The genomic DNA G+C content of the type strain is $72 \pm 0.3 \mathrm{~mol} \%$.

\section{References}

Behrendt, U., Ulrich, A. \& Schumann, P. (2001). Description of Microbacterium foliorum sp. nov. and Microbacterium phyllosphaerae sp. nov., isolated from the phyllosphere of grasses and the surface litter after mulching the sward, and reclassification of Aureobacterium resistens (Funke et al. 1998) as Microbacterium resistens comb. nov. Int J Syst Evol Microbiol 51, 1267-1276.

Brennan, N. M., Brown, R., Goodfellow, M., Ward, A. C., Beresford, T. P., Vancanneyt, M., Cogan, T. M. \& Fox, P. F. (2001). Microbacterium gubbeenense sp. nov., from the surface of a smearripened cheese. Int J Syst Evol Microbiol 51, 1969-1976.

Epstein, E. (1997). The Science of Composting. Lancaster, PA: Technomic Publishing.

Euzéby, J. P. (1997). List of Bacterial Names with Standing in Nomenclature: a folder available on the Internet. Int J Syst Bacteriol 47, 590-592. (List of Prokaryotic Names with Standing in Nomenclature. Last full update May 02, 2008 URL: http://www. bacterio.net).

Ferreira da Silva, M., Tiago, I., Veríssimo, A., Boaventura, R. A. R., Nunes, O. C. \& Manaia, C. M. (2006). Antibiotic resistance of enterococci and related bacteria in an urban wastewater treatment plant. FEMS Microbiol Ecol 55, 322-329.

Ferreira da Silva, M., Vaz-Moreira, I., Gonzalez-Pajuelo, M., Nunes, O. C. \& Manaia, C. M. (2007). Antimicrobial resistance patterns in Enterobacteriaceae isolated from an urban wastewater treatment plant. FEMS Microbiol Ecol 60, 166-176.

Jukes, T. H. \& Cantor, C. R. (1969). Evolution of protein molecules. In Mammalian Protein Metabolism, vol. 3, pp. 21-132. Edited by H. N. Munro. New York: Academic Press.

Komagata, K. \& Suzuki, K.-I. (1984). Genus Aureobacterium Collins, Jones, Keddie, Kroppenstedt and Schleifer 1983, 672 ${ }^{\text {VP }}$. In Bergey's Manual of Systematic Bacteriology, vol. 2, pp. 1323-1325. Edited by J. T. Staley, M. P. Bryant, N. Pfennig \& J. G. Holt. Baltimore: Williams \& Wilkins.

Kumar, S., Tamura, K. \& Nei, M. (2004). MEGA3: Integrated software for molecular evolutionary genetics analysis and sequence alignment. Brief Bioinform 5, 150-163.

MacKenzie, S. L. (1987). Gas chromatographic analysis of amino acids as the $N$-heptafluorobutyryl isobutyl esters. J Assoc Off Anal Chem 70, 151-160.

Matsuyama, H., Kawasaki, K., Yumoto, I. \& Shida, O. (1999). Microbacterium kitamiense sp. nov., a new polysaccharide-producing bacterium isolated from the wastewater of a sugar-beet factory. Int $\mathrm{J}$ Syst Bacteriol 49, 1353-1357.

Mesbah, M., Premachandran, U. \& Whitman, W. B. (1989). Precise measurement of the $\mathrm{G}+\mathrm{C}$ content of deoxyribonucleic acid by highperformance liquid chromatography. Int J Syst Bacteriol 39, 159-167.

Murray, R. G. E., Doetsch, R. N. \& Robinow, F. (1994). Determinative and cytological light microscopy. In Methods for General and Molecular Bacteriology, pp. 21-41. Edited by P. Gerhardt, R. G. E. Murray, W. A. Wood \& N. R. Krieg. Washington, DC: American Society for Microbiology.

Rhuland, L. E., Work, E., Denman, R. F. \& Hoare, D. S. (1955). The behavior of the isomers of $\alpha, \varepsilon$-diaminopimelic acid on paper chromatograms. J Am Chem Soc 77, 4844-4846. 
Richert, K., Brambilla, E. \& Stackebrandt, E. (2007). The phylogenetic significance of peptidoglycan types: molecular analysis of the genera Microbacterium and Aureobacterium based upon sequence comparison of $g y r B, r p o B, r e c A$ and $p p k$ and $16 \mathrm{~S}$ rRNA genes. Syst Appl Microbiol 30, 102-108.

Schippers, A., Bosecker, K., Spröer, C. \& Schumann, P. (2005). Microbacterium oleivorans sp. nov. and Microbacterium hydrocarbonoxydans sp. nov., novel crude-oil-degrading Gram-positive bacteria. Int J Syst Evol Microbiol 55, 655-660.

Schleifer, K. H. \& Seidl, P. H. (1985). Chemical composition and structure of murein. In Chemical Methods in Bacterial Systematics, pp. 201-219. Edited by M. Goodfellow \& D. E. Minnikin. London: Academic Press.

Schumann, P., Prauser, H., Rainey, F. A., Stackebrandt, E. \& Hirsch, P. (1997). Friedmanniella antarctica gen. nov., sp. nov., an LL-diaminopimelic acid-containing actinomycete from Antarctic sandstone. Int J Syst Bacteriol 47, 278-283.

Shivaji, S., Bhadra, B., Rao, R. S., Chaturvedi, P., Pindi, P. K. \& Raghukuma, C. (2007). Microbacterium indicum sp. nov., isolated from a deep-sea sediment sample from the Chagos Trench, Indian Ocean. Int J Syst Evol Microbiol 57, 1819-1822.

Smibert, R. M. \& Krieg, N. R. (1994). Phenotypic characterization. In Methods for General and Molecular Bacteriology, pp. 607-654. Edited by P. Gerhardt, R. G. E. Murray, W. A. Wood \& N. R. Krieg. Washington, DC: American Society for Microbiology.
Staneck, J. L. \& Roberts, G. D. (1974). Simplified approach to identification of aerobic actinomycetes by thin-layer chromatography. Appl Microbiol 28, 226-231.

Takeuchi, M. \& Hatano, K. (1998a). Union of the genera Microbacterium Orla-Jensen and Aureobacterium Collins et al. in a redefined genus Microbacterium. Int J Syst Bacteriol 48, 739-747.

Takeuchi, M. \& Hatano, K. (1998b). Proposal of six new species in the genus Microbacterium and transfer of Flavobacterium marinotypicum ZoBell and Upham to the genus Microbacterium as Microbacterium maritypicum comb. nov. Int J Syst Bacteriol 48, 973-982.

Tiago, I., Teixeira, I., Silva, S., Chung, P., Veríssimo, A. \& Manaia, C. M. (2004). Metabolic and genetic diversity of mesophilic and thermophilic bacteria isolated from composted municipal sludge on poly- $\varepsilon$-caprolactones. Curr Microbiol 49, 407-414.

Tindall, B. J. (1989). Fully saturated menaquinones in the archaebacterium Pyrobaculum islandicum. FEMS Microbiol Lett 60, 251-254.

Uchida, K., Kudo, T., Suzuki, K. \& Nakase, T. (1999). A new rapid method of glycolate test by diethyl ether extraction, which is applicable to a small amount of bacterial cells of less than one milligram. J Gen Appl Microbiol 45, 49-56.

Vaz-Moreira, I., Nobre, M. F., Nunes, O. C. \& Manaia, C. M. (2007). Gulbenkiania mobilis gen. nov., sp. nov., isolated from treated municipal wastewater. Int J Syst Evol Microbiol 57, 1108-1112.

Vaz-Moreira, I., Silva, M. E., Manaia, C. M. \& Nunes, O. C. (2008). Diversity of bacterial isolates from commercial and homemade composts. Microb Ecol 55, 714-722. 